\title{
Nitric oxide is not involved in the initiation of insulin secretion from rat islets of Langerhans
}

\author{
P.M.Jones, S.J.Persaud, T. Bjaaland, J.D.Pearson and S. L. Howell \\ Biomedical Sciences Division, King's College London, London, UK
}

\begin{abstract}
Summary. The involvement of nitric oxide as an intracellular messenger in the control of insulin secretion from pancreatic Beta cells was studied in rat islets of Langerhans by measuring: (i) nitric oxide generation in response to physiological insulin secretagogues; (ii) the effects of inhibitors of nitric oxide synthesis on insulin secretory responses to physiological secretagogues, and on insulin synthesis; (iii) changes in islet cyclic guanosine monophosphate in response to secretagogues; (iv) the effects of exogenous cyclic guanosine monophosphate and dibutyryl cyclic guanosine monophosphate on insulin secretion from electrically permeabilised islets and
\end{abstract}

from intact islets, respectively. These studies produced no evidence that nitric oxide generation is required for the initiation of insulin secretion by common secretagogues. However, the results of our experiments suggest that the generation of nitric oxide may be involved in long-term, glucose-dependent increases in cyclic guanosine monophosphate content of islet cells, although the physiological relevance of these changes requires further investigation.

Key words: Islet of Langerhans, insulin secretion, nitric oxide, cyclic guanosine monophosphate.
The release of insulin from pancreatic Beta cells is closely regulated by circulating concentrations of nutrients, such as glucose, and by certain hormones and neurotransmitters. These different types of secretagogues appear to control the secretory process by changing the concentration/availability of a number of intracellular regulatory molecules. Changes in Beta-cell cytosolic $\mathrm{Ca}^{2+}$, whether by an influx of extracellular $\mathrm{Ca}^{2+}$ or a liberation of intracellular stores of $\mathrm{Ca}^{2+}$, are thought to be of prime importance in the initiation of insulin secretion [1]. Secretory responses to $\mathrm{Ca}^{2+}$ can be modified by cyclic nucleotides and products of phospholipid hydrolysis, such as diacylglycerols, or arachidonic acid or its metabolites, or both [1]. Nitric oxide (NO), recently identified as endotheliumderived relaxing factor [2], acts as a signalling molecule in many cell types and there have been recent reports that NO may be generated within the islets of Langerhans [3-5] and insulin-secreting tumour cells $[4,5]$. NO is generated from the amino acid arginine by nitric oxide synthase (NO-synthase), an enzyme activity which appears to exist in two distinct forms, both of which require NADPH [6]. One form of NO synthase, which is found in endothelial cells, is constitutively expressed and is activated by $\mathrm{Ca}^{2+}$ in sub-micromolar concentrations [6]. Our previous studies using electrically permeabilised islets have demonstrated that increases in cytosolic $\mathrm{Ca}^{2+}$ alone are sufficient to initiate insulin secretion $[7,8]$. The constitutive, $\mathrm{Ca}^{2+}$-sensitive NO-synthase therefore offers a potential regulatory mechanism for Beta-cell secretory responses to $\mathrm{Ca}^{2+}$-mobilising secretagogues such as glucose or cholinergic agonists. The other form of NO-synthase, which is found in macrophages, is inducible, insensitive to changes in intracellular $\mathrm{Ca}^{2+}$, and generates large amounts of $\mathrm{NO}$ in an unregulated manner after induction [6]. In the present study we have used several experimental approaches to determine the role, if any, of NO in the initiation of Beta-cell secretory responses.

Several methods for detecting the generation of NO have been described. For example, chemical measurements of nitrites in an incubation medium give an indication of prior NO production [3]. Other assays for NO production are based on measuring increases in guanylate cyclase activity or guanosine $3^{\prime}, 5^{\prime}$-cyclic monophosphate (cyclic GMP) concentrations in target tissues [9], or by measuring some functional consequence of elevated cyclic GMP, such as relaxation of smooth muscle $[2,10]$. Alternatively, an on-line estimation of NO generation can be obtained by monitoring the conversion of oxy-haemoglobin (oxy-Hb) to methaemoglobin (met- $\mathrm{Hb}$ ) as a result of the reaction of NO with the haem moiety of haemoglobin, with the resultant production of nitrate ions [9]. Using this approach we have directly compared insulin re- 
lease and NO production from perifused rat islets in response to nutrient and non-nutrient secretagogues.

Analogues of arginine, such as $\mathrm{N}^{\mathrm{G}}$-monomethyl-L-arginine (NMA) or N-nitro-L-arginine methyl ester (NAME) are competitive inhibitors of both isoforms of NO synthase, albeit with differing potencies [11]. We have used these arginine analogues to determine whether inhibition of NO synthase activity results in a parallel inhibition of insulin secretion from isolated rat islets of Langerhans. A major intracellular target for NO appears to be the haem moiety of soluble guanylate cyclase [12]. The reaction of NO with haem causes the activation of guanylate cyclase, leading to elevated levels of intracellular cyclic GMP. We have therefore measured the effects of insulin secretagogues, and of NMA and NAME, on the accumulation of endogenous cyclic GMP in islets. To determine whether NO-induced changes in islet cyclic GMP could be involved in regulating the secretory process, we have measured the effects of exogenous cyclic GMP on $\mathrm{Ca}^{2+}$ induced insulin secretion from electrically permeabilised islets, and of dibutyryl cyclic GMP (db-cyclic GMP) on glucose-induced insulin secretion from intact islets.

\section{Materials and methods}

\section{Materials}

Rats (Wistar WAG 150-200 g) were supplied by Charing Cross Hospital Medical School, London, UK. Cyclic 2'-O-succinyl-GMP $3-\left[{ }^{125} \mathrm{I}\right]$ iodotyrosine was from New England Nuclear corporation (Boston, Mass., USA). Na[ $\left.{ }^{[125} \mathrm{I}\right]$ for insulin iodination and $\left[{ }^{35} \mathrm{~S}\right]$-cysteine were from Amersham International (Amersham, Bucks., UK). Reagents for tissue culture were from Gibco (Uxbridge, Middlesex, UK). Pansorbin was from Calbiochem (Novabiochem UK Ltd., Nottingham, UK). All other reagents were of analytical grade from Sigma Chemical Co. (Poole, Dorset, UK) or from BDH (Poole, Dorset, UK).

\section{Tissue isolation and culture}

Islets of Langerhans were isolated from fed Wistar rats by collagenase digestion of the exocrine pancreas [13], and incubated $\left(37^{\circ} \mathrm{C}\right.$, $95 \%$ air $75 \% \mathrm{CO}_{2}$ ) for $16-20 \mathrm{~h}$ in RPMI 1640 culture medium containing $2 \mathrm{mmol} / \mathrm{l}$ glucose or $11 \mathrm{mmol} / \mathrm{l}$ glucose, and supplemented with $10 \%$ (volume/volume, v/v) fetal calf serum, $100 \mu \mathrm{g}$ of streptomycin $/ \mathrm{ml}$, 100 units of penicillin $/ \mathrm{ml}$ and, for some experiments, $100 \mu \mathrm{mol} / 1$ or $200 \mu \mathrm{mol} / \mathrm{l} \mathrm{NMA}$ or NAME. Before use in secretion experiments, islets were thoroughly washed and incubated $(60 \mathrm{~min}$, $37^{\circ} \mathrm{C}$ ) in a physiological salt solution [14] containing $2 \mathrm{mmol} / \mathrm{l} \mathrm{glu-}$ cose and, where appropriate, NMA or NAME at the same concentration as was present during the culture period.

Isolated porcine aortic endothelial cells were subcultured once, grown to confluence on microcartier beads and transferred to $0.5 \mathrm{ml}$ columns $\left(\sim 2.5 \times 10^{6}\right.$ cells $)$ as described [15], for perifusion at $0.8 \mathrm{ml} / \mathrm{min}$ with Krebs buffer supplemented with the test substances of interest.

\section{NO measurements}

NO release from perifused islets and porcine aortic endothelial cells was assessed by measuring the conversion of oxy- $\mathrm{Hb}$ to met-Hb by continuous monitoring of the difference spectrum of the perifusate at 401 and $411 \mathrm{~nm}$ using a double wavelength spectrophotometer, essentially as described [9]. The perifusion buffer was supplemented with $4 \mu \mathrm{mol} / \mathrm{l}$ oxy-Hb with an absorption maximum of $415 \mathrm{~nm}$, prepared according to the method of Feelisch and Noack [9]. The molsidomine metabolite SIN-1 $(0.1-10 \mu \mathrm{mol} / 1)$, which spontaneously generates $\mathrm{NO}$, was used to validate and to calibrate the system. Changes in absorbance were converted into secretion rates for NO using a molar extinction coefficient of $60 \mathrm{mmol} \cdot \mathrm{I}^{-1} \cdot \mathrm{cm}^{-1}$ measured for oxy-Hb in these studies, as described [9].

\section{Measurements of islet cyclic nucleotide content}

Groups of $50-100$ islets were incubated $\left(15\right.$ or $\left.30 \mathrm{~min}, 37^{\circ} \mathrm{C}\right)$ in physiological buffer [14] containing the insulin secretagogue of interest plus $100 \mu \mathrm{mol} / \mathrm{l}$ isobutylmethylxanthine (IBMX). After incubation the islets were pelleted by brief centrifugation $(9000 \mathrm{~g}, 15 \mathrm{~s})$, the supernatant was removed for insulin assay and the islet pellet was extracted by boiling ( $3 \mathrm{~min}$ ) and sonication in sodium acetate buffer. Cyclic GMP was measured by radioimmunoassay using an antiserum raised against cyclic 2'-O-succinyl-GMP which was kindly donated by Dr. D. Sugden, Biomedical Sciences Division, King's College London. Cyclic GMP standards and samples $(50 \mu 1)$ were acetylated before inclusion in the assay by addition of $5 \mu \mathrm{l}$ tricthylamine: acetic anhydride $(2: 1 \mathrm{v} / \mathrm{v})$, and cyclic 2'-O-succinyl-GMP $3-\left[{ }^{125} \mathrm{I}\right]$ iodotyrosine was used as the radiolabelled tracer. Incubation was for $48 \mathrm{~h}$ at $4^{\circ} \mathrm{C}$ and antibody-bound cyclic GMP was precipitated by $12 \%$ (weight/volume, w/v) polyethylene glycol. Under these conditions the detection limit of the assay was approximately 0.5 fmol cyclic GMP per tube, with a useful range of $0.5-250 \mathrm{fmol} \mathrm{cy-}$ clic GMP per tube. In some experiments, islet cyclic AMP content was measured by radioimmunoassay, as previously described [16].

\section{Insulin secretion studies}

(a) Perifusions. Groups of $800-1500$ islets (approximately $2-4 \times 10^{6}$ cells) were transferred to Millipore Swinnex filter chambers containing $1 \mu \mathrm{m}$ mesh filters and perifused at a flow rate of $0.8 \mathrm{ml} / \mathrm{min}$ with Krebs buffer supplemented with the test substances of interest. NO generation by the islets was continuously assessed as described above and fractions were collected at 1-min intervals for measurement of insulin release by radioimmunoassay [17].

(b) Static incubations. To measure the effects of NMA, NAME or $\mathrm{db}$-cyclic GMP on insulin secretion, groups of three islets were incubated $\left(30 \mathrm{~min}, 37^{\circ} \mathrm{C}\right)$ in $0.6 \mathrm{ml}$ of a physiological salt solution supplemented with 2,10 or $20 \mathrm{mmol} / \mathrm{l}$ glucose, $2 \mathrm{mmol} / \mathrm{l} \mathrm{CaCl}_{2}$, $0.5 \mathrm{mg} / \mathrm{ml}$ of bovine serum albumen and the test substances of interest, and insulin secretion was measured by radioimmunoassay.

(c) Electrically permeabilised islets. The effects of exogenous cyclic GMP on insulin secretion were investigated using islets permeabilised by high voltage discharge, as previously described [7]. Groups of five electrically permeabilised islets were incubated ( $30 \mathrm{~min}, 37^{\circ} \mathrm{C}$ ) in a glutamate-based $\mathrm{Ca}^{2+} / \mathrm{EGTA}$ buffer containing $50 \mathrm{nmol} / \mathrm{l}$ or $10 \mu \mathrm{mol} / 1 \mathrm{Ca}^{2+}$ in the presence or absence of cyclic GMP or cyclic AMP.

\section{Insulin content and synthesis}

The effects of NMA and NAME on (pro)insulin synthesis were assessed by measuring the incorporation of a radiolabelled amino acid into (pro)insulin after immunoprecipitation of islet extracts. Islets were incubated for $20 \mathrm{~h}$ in RPMI 1640 medium containing $2 \mathrm{mmol} / \mathrm{l}$ or $11 \mathrm{mmol} / \mathrm{l}$ glucose supplemented with NMA or NAME $(200 \mu \mathrm{mol} / 1)$. Groups of 50 islets were further incubated $(100 \mu)$, $\left.3 \mathrm{~h}, 37^{\circ} \mathrm{C}\right)$ in fresh medium supplemented with $\left[{ }^{35} \mathrm{~S}\right]$-cysteine $(150 \mu \mathrm{Ci} / \mathrm{ml} ;>1000 \mathrm{Ci} / \mathrm{mmol})$. The islets were washed $(2 \times 1 \mathrm{ml})$ and incubated $\left(1 \mathrm{~h}, 37^{\circ} \mathrm{C}\right)$ in RPMI 1640 medium ( 2 mmol/l glucose) supplemented with $2 \mathrm{mmol} / 1$ cysteine. After two further washes $(2 \times 1 \mathrm{ml})$ with RPMI 1640 supplemented with $2 \mathrm{mmol} / /$ cysteine the 

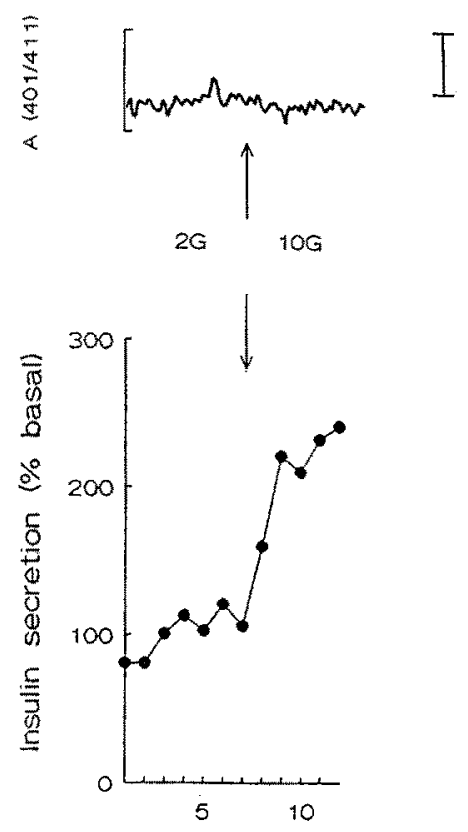
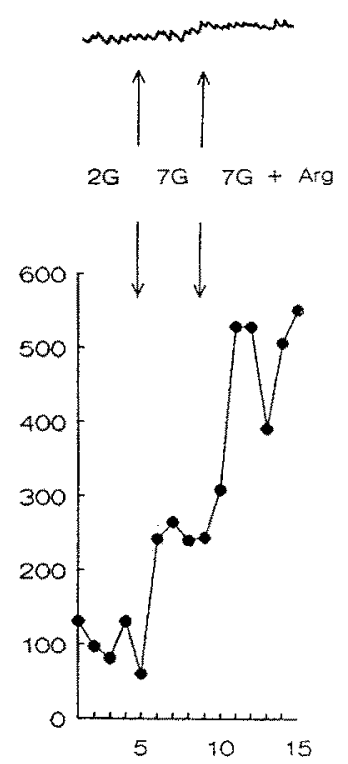
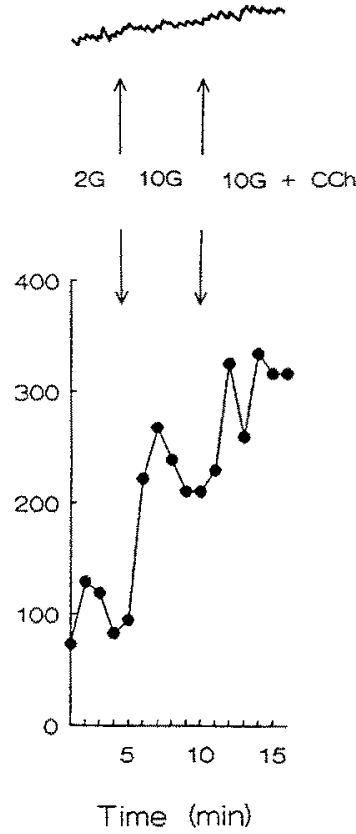

Fig. 1. Simultaneous assessment of nitric oxide (NO) production and insulin secretion from perifused islets. Islets were perifused with a buffer containing oxy-haemoglobin supplemented with $2 \mathrm{mmol} / \mathrm{l}$ glucose $(2 \mathrm{G})$. Insulin secretion (bottom traces) was stimulated by switching to a perifusate containing $7 \mathrm{mmol} / 1$ or $10 \mathrm{mmol} / \mathrm{lglucose}(7 \mathrm{G}$ or $10 \mathrm{G}$ ), and further potentiated by exposure to carbachol $(\mathrm{CCh}, 500 \mu \mathrm{mol} / \mathrm{l})$ or arginine (Arg, $10 \mathrm{mmol} / \mathrm{l}$ ), as indicated by the arrows. The stimulation of insulin secretion was not accompanied by detectable increases in NO generation as assessed by continuous monitoring of the difference spectra at 401 and $411 \mathrm{~nm}$ (top traces). The figures show traces from real-time recordings; vertical bar shows a deflection of 0.002 absorbance units islets were lysed by sonication (MSE Soniprobe, $15 \mathrm{~s}, 1 \mu, 4^{\circ} \mathrm{C}$ ) in $100 \mu \mathrm{l}$ of a buffer containing $50 \mathrm{mmol} / \mathrm{l}$ Tris $/ \mathrm{HCl}, 1 \%$ (v/v) Triton $\mathrm{X}-100,0.1 \%(\mathrm{w} / \mathrm{v})$ sodium azide, $0.1 \mathrm{mmol} / \mathrm{l}$ sodium fluoride, $0.1 \mathrm{mmol} / 1$ leupeptin, $0.01 \mathrm{mmol} / \mathrm{L}-64,0.01 \mathrm{mmol} / 1$ tosyllysine chloromethyl ketone, $0.01 \mathrm{mmol} / 1$ phenylmethylsulphonyl fluoride, pH 8.0. Anti-insulin serum [17] was added $(2 \mu$ neat serum $/ 100 \mu 1$ sample) and samples were incubated at $4^{\circ} \mathrm{C}$ for $24 \mathrm{~h}$. (Pro)insulin bound to anti-insulin antibodies was precipitated by the addition of Pansorbin $(20 \mu)$ and incubation with constant mixing $\left(20^{\circ} \mathrm{C}, 2 \mathrm{~h}\right)$, followed by precipitation of the Pansorbin by centrifugation $(9000 \mathrm{~g}$, $1 \mathrm{~min})$. The resulting pellet was washed $\left(\times 4,4^{\circ} \mathrm{C}\right)$ with lysis buffer and ${ }^{35} \mathrm{~S}$ incorporation into immunoprecipitated proteins in the pellets was measured by liquid scintillation spectroscopy. In parallel experiments, islet insulin content was measured by radioimmunoassay after extraction in acidified ethanol $(10$ islets $/ 200 \mu l)$.

\section{Results}

\section{Effects of insulin secretagogues on islet NO production}

Increasing the concentration of glucose in the perifusate from $2 \mathrm{mmol} / \mathrm{l}$ to $10 \mathrm{mmol} / \mathrm{l}$ caused a rapid increase in insulin secretion from perifused islets, as shown in Figure 1 (lower traces). This initial, rapid rise in insulin secretion represents the first, transient phase of the secretory response to nutrient secretagogues. Glucose-induced insulin secretion was further enhanced by the presence of the cholinergic agonist carbachol $(\mathrm{CCh}, 500 \mu \mathrm{mol} / \mathrm{l})$ or by arginine (Arg, $10 \mathrm{mmol} / \mathrm{l}$ ). However, neither glucose alone, glucose plus CChn or glucose plus arginine stimulated the release of detectable amounts of NO from these perifused islets, as judged by the unchanged signal from the oxy-Hb/met- $\mathrm{Hb}$ difference spectra shown on Figure 1 (upper traces). In similar experiments, insulin secretion was significantly stimulated by perifusion with buffers containing a higher concentration of arginine $(20 \mathrm{mmol} / \mathrm{l}$, $161 \pm 12 \%$ control, mean $\pm \operatorname{SEM}, n=6, p<0.01$ ), or the protein kinase $\mathrm{C}$ activator, phorbol myristate acetate (PMA, $500 \mathrm{nmol} / \mathrm{l}, 160 \pm 24 \%$ control, $n=6, p<0.05$ ) again without detectable effects on $\mathrm{NO}$ generation by the islets. In contrast, NO generation was readily detected in parallel experiments using porcine aortic endothelial cells. Figure 2 (upper trace) shows the rapid and reproducible effects of bradykinin on NO generation by porcine aortic endothelial cells as judged by changes in the difference spectra of the $\mathrm{Hb}$-containing perifusate at $401 \mathrm{~nm}$ and $411 \mathrm{~nm}$. In this experiment, $200 \mathrm{nmol} / 1 \mathrm{brady}-$ kinin can be calculated to have produced a maximum rate of NO generation of $90 \mathrm{pmol} \mathrm{NO} \cdot \mathrm{min}^{-1} \cdot 10^{6} \mathrm{cells}^{-1}$. Figure 2 (lower trace) also shows the effects of SIN-1 on the $401 \mathrm{~nm} / 411 \mathrm{~nm}$ difference spectra in the absence of cells. Assuming that SIN-1 has a stoichiometric effect to that of NO in this system [9], the lower detection limit for NO generation in these experiments was less than $10 \mathrm{pmol}$ $\mathrm{NO} \cdot \mathrm{min}^{-1} \cdot 10^{6}$ cells $^{-1}$.

\section{Effects of insulin secretagogues on islet cyclic GMP content}

Freshly isolated rat islets contained low but detectable amounts of cyclic GMP, which were approximately 100 fold lower than unstimulated islet cyclic AMP content. However, the results shown in Table 1 demonstrate that islet cyclic GMP content increased markedly (5-10 fold) after $20 \mathrm{~h}$ of culture in RPMI 1640 medium containing $11 \mathrm{mmol} / 1$ glucose. Short incubations (15 min) with $20 \mathrm{mmol} / \mathrm{l}$ glucose caused significant increases in islet cyclic AMP content ( $2 \mathrm{mmol} / \mathrm{l}$ glucose, $14.5 \pm 1.0 \mathrm{fmol} / \mathrm{islet}$; $20 \mathrm{mmol} / \mathrm{l}$ glucose, $27.7 \pm 1.2$, mean $\pm \mathrm{SEM}, n=10$, $p<0.01$ ), but 15 -min incubations with stimulatory concentrations of glucose $(20 \mathrm{mmol} / \mathrm{l})$, arginine $(10 \mathrm{mmol} / \mathrm{l})$ or CCh $(500 \mu \mathrm{mol} / \mathrm{l})$ were without detectable effects on the cyclic GMP content of either freshly isolated islets or of cultured islets, as shown in Table 1. Note, however, that longer exposures $(30 \mathrm{~min}$ ) to $20 \mathrm{mmol} / 1$ glucose in the presence of $100 \mathrm{umol} / 1 \mathrm{IBMX}$ produced small, but signifi- 

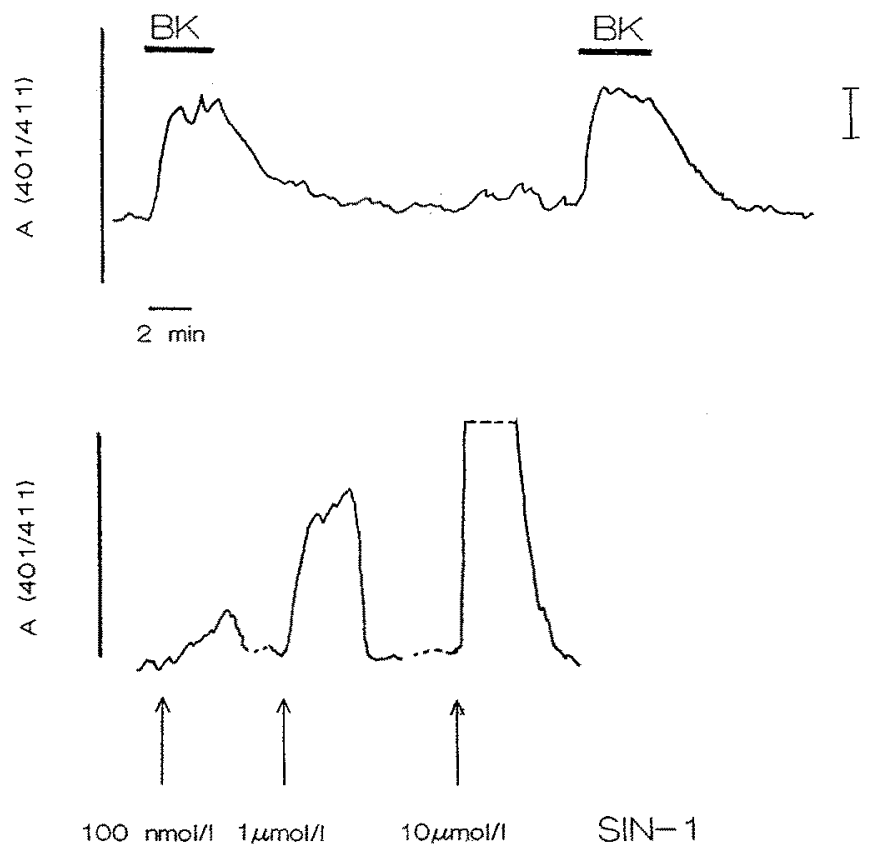

Fig. 2. Nitric oxide (NO) production by endothelial cells. Upper traces: The inclusion of bradykinin (BK, $200 \mathrm{nmol} /$ ) in the perifusate (shown by the horizontal bar) produced reproducible increases in NO release by porcine aortic endothelial cells. Lower traces: Calibration of the system using the molsidomine metabolite SIN-1 $(100 \mathrm{nmol} / \mathrm{l}-10 \mu \mathrm{mol} / \mathrm{l})$ indicated a detection limit in these experiments of at least $10 \mathrm{pmol} \mathrm{NO} \cdot \mathrm{min}^{-1} \cdot 10^{6} \mathrm{cells}^{-1}$. The figures show traces from real-time recordings; vertical bar shows a deflection of 0.002 absorbance units

cant $(p<0.05)$, increases in islet cyclic GMP $(153 \pm 12 \%$ basal, mean \pm SEM, $n=8$ ).

The marked increases in islet cyclic GMP observed after the $20 \mathrm{~h}$ culture period were dependent upon the concentration of glucose in the culture medium, as shown in Figure 3. Thus, increases in cyclic GMP content were observed after $20 \mathrm{~h}$ culture in RPMI 1640 containing $11 \mathrm{mmol} / \mathrm{l}$ glucose, but not after $20 \mathrm{~h}$ culture in the same medium containing $2 \mathrm{mmol} / \mathrm{l}$ glucose. Furthermore, these glucose-dependent increases in islet cyclic GMP could be totally abolished by the presence of either NMA or NAME $(200 \mu \mathrm{mol} / \mathrm{l})$ in the culture medium (Fig. 3). In the experiment shown in Figure 3, NMA (but not NAME) reduced islet cyclic GMP content below that measured in control islets ( $2 \mathrm{mmol} / \mathrm{l}$ glucose $)$. However, in four separate experiments of this type NMA $(200 \mu \mathrm{mol} / \mathrm{l}) \mathrm{did}$ not consistently produce such a reduction in basal levels of cyclic GMP (control, $2 \mathrm{mmol} / \mathrm{l}$ glucose, $173 \pm 27 \mathrm{amol} / \mathrm{islet}$; $+\mathrm{NMA}, 146 \pm 38, p>0.2, n=4)$.

\section{Effects of NO synthase inhibitors on insulin secretion and synthesis}

The NO synthase inhibitors, NMA and NAME, did not inhibit glucose-induced insulin secretion during a 30-min incubation in the absence of exogenous arginine, as shown in Figure 4. Under these static incubation conditions, insulin secretion by the islets reflects both the transient first phase and the prolonged second phase responses to nutrient secretagogues. When used at concentrations well above those known to inhibit NO synthase activity [11], NMA had no consistent effect on glucose-induced $(10 \mathrm{mmol} / \mathrm{l}$ or $20 \mathrm{mmol} / \mathrm{l}$ ) insulin secretion (Fig. 4, upper panel). In similar experiments, NAME was also without inhibitory effects on glucose-induced insulin secretion, even when used at concentrations up to $1 \mathrm{mmol} / \mathrm{l}$ (Fig. 4, lower panel).

The failure of NMA and NAME to inbibit insulin secretion was not because of too short an exposure to these agents, since even 20-24 h exposure to NMA or NAME ( $200 \mu \mathrm{mol} / 1)$ did not inhibit subsequent insulin secretory responses, although such treatment did have marked effects on islet cyclic GMP content (Fig.3). Figure 5 shows that prolonged treatment with NMA or NAME (in the presence of $11 \mathrm{mmol} / 1$ glucose) did not affect basal insulin release ( $2 \mathrm{mmol} / \mathrm{l}$ glucose $)$, nor secretory responses to $20 \mathrm{mmol} / 1$ glucose or to arginine $(20 \mathrm{mmol} / 1)$. In similar experiments, prolonged treatment with NMA $(200 \mu \mathrm{mol} / 1,20 \mathrm{~h})$ did not affect insulin secretion induced by the cholinergic agonist $\mathrm{CCh}$ in the presence of $10 \mathrm{mmol} / \mathrm{l}$ glucose (controls, $10 \mathrm{mmol} / \mathrm{l}$ glucose + $500 \mu \mathrm{mol} / 1 \mathrm{CCh}, 392 \pm 44 \%$ of secretion with $10 \mathrm{mmol} / \mathrm{l}$ glucose alone; NMA-treated, $10 \mathrm{mmol} / \mathrm{l}$ glucose + $500 \mu \mathrm{mol} / \mathrm{l} \quad \mathrm{CCh}, \quad 332 \pm 28 \%, \quad$ mean $\pm \mathrm{SEM}, \quad n=9$, $p>0.2$ ).

Prolonged treatment with NMA or NAME $(200 \mu \mathrm{mol} / \mathrm{l}) \mathrm{had}$ no detectable effect on insulin biosynthesis, as shown in Figure 6. Thus, incubation for $20 \mathrm{~h}$ in RPMI 1640 medium containing $11 \mathrm{mmol} / \mathrm{l}$ glucose produced a small but significant $(p<0.02)$ increase in islet insulin content when compared to control islets cultured in the presence of $2 \mathrm{mmol} / \mathrm{l}$ glucose, but insulin content was neither enhanced nor diminished by the presence of NMA or NAME. Similarly, incorporation of $\left[{ }^{35} \mathrm{~S}\right]$-cysteine into (pro)insulin was significantly enhanced by exposure to $11 \mathrm{mmol} / 1$ glucose when compared to control islets exposed to $2 \mathrm{mmol} / \mathrm{lglucose}$, but this glucose-induced stimu-

Table 1. Effects of insulin secretagogues on cyclic guanosine monophosphate (cyclic GMP) levels in fresh and cultured islets

\begin{tabular}{ll}
\hline Fresh islets & $\begin{array}{c}\text { Cyclic GMP } \\
\text { (amol/islet) }\end{array}$ \\
\hline $2 \mathrm{mmol} / /$ glucose & $145 \pm 15$ \\
$7 \mathrm{mmol} / \mathrm{l}$ glucose & $160 \pm 12$ \\
$20 \mathrm{mmol} / \mathrm{glucose}$ & $130 \pm 43$ \\
$7 \mathrm{mmol} / \mathrm{glucose}+10 \mathrm{mmol} / \mathrm{l}$ arginine & $144 \pm 15$ \\
Cultured islets & \\
\hline $2 \mathrm{mmol} / \mathrm{glucose}$ & $1020 \pm 150$ \\
$20 \mathrm{mmol} / /$ glucose & $810 \pm 30$ \\
$20 \mathrm{mmol} / \mathrm{glucose}+500 \mu \mathrm{mol} / \mathrm{CCh}$ & $910 \pm 110$ \\
\hline
\end{tabular}

Cyclic guanosine monophosphate (cyclic GMP) was measured in is lets incubated for $15 \mathrm{~min}$ at $37^{\circ} \mathrm{C}$ in the presence of various insulin secretagogues, as shown, plus $100 \mu \mathrm{mol} / \mathrm{IBMX}$. None of the secretagogues tested had significant effects on islet cyclic GMP. Note, however, that islets cultured $(20 \mathrm{~h})$ in RPMI $1640(11 \mathrm{mmol} / 1 \mathrm{glu}-$ cose) contained considerably elevated levels of cyclic GMP, although these levels were not further affected by a subsequent incubation in the presence of stimulatory concentrations of glucose or carbachol (CCh). Values are means \pm SEM, $n=5-7$ 


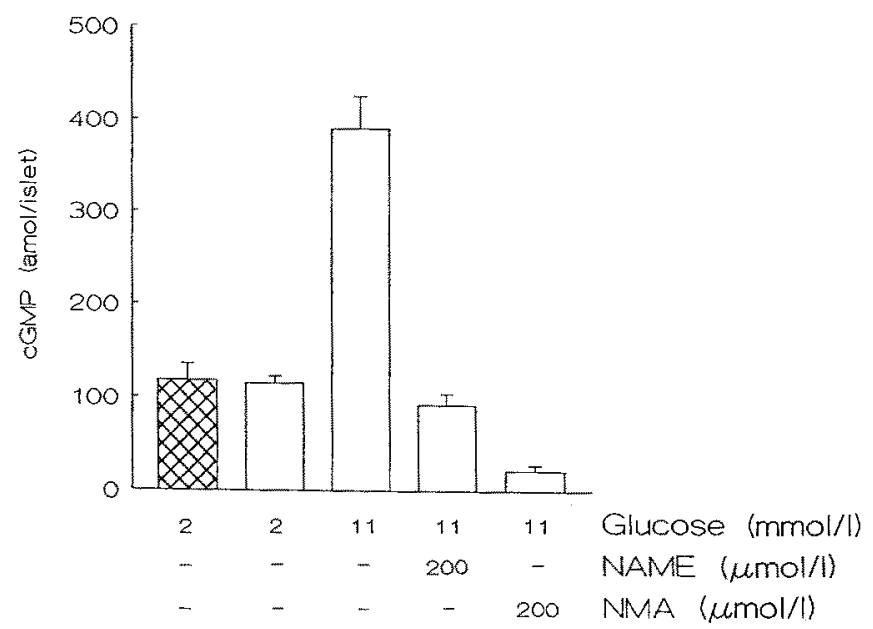

Fig. 3. Cyclic guanosine monophosphate (cyclic GMP) in cultured islets: effects of glucose, $\mathrm{N}^{\mathrm{G}}$-monomethyl-L-arginine (NMA) and $\mathrm{N}$ nitro-L-arginine methyl ester (NAME). The figure shows cyclic GMP levels in freshly isolated islets (ख) and in islets cultured for $20 \mathrm{~h}$ in RPMI 1640 medium containing 2 or $11 \mathrm{mmol} / \mathrm{lglucose}$ in the presence or absence of NMA or NAME, as shown. Culture in medium containing $2 \mathrm{mmol} / 1$ glucose was without effect on islet cyclic GMP $(p>0.2)$, whereas culture in the same medium containing $11 \mathrm{mmol} / \mathrm{h}$ glucose caused marked increases in islet cyclic GMP $(p<0.01)$. The glucose-induced elevations in islet cyclic GMP were totally inhibited by both NAME and NMA. Bars show means $+\mathrm{SEM}, n=8$ or 9

lation of insulin biosynthesis was not affected by the presence of either NMA or NAME (Fig. 6).

\section{Effects of cyclic GMP and db-cyclic GMP on insulin secretion}

Figure 7 shows the effects of db-cyclic GMP on insulin secretion from intact islets (upper panel) and of cyclic GMP from electrically permeabilised islets (lower panel). In intact islets, insulin secretion was markedly stimulated in the presence of $20 \mathrm{mmol} / \mathrm{l}$ glucose (plus $100 \mu \mathrm{mol} / \mathrm{l}$ IBMX). However, concentrations of up to $5 \mathrm{mmol} / \mathrm{ldb}-\mathrm{cy}-$ clic GMP had no effect on either basal ( $2 \mathrm{mmol} / \mathrm{l}$ glucose) or stimulated ( $20 \mathrm{mmol} / 1$ glucose $)$ insulin secretion (Fig. 7 , upper panel). In similar experiments, $1 \mathrm{mmol} / 1$ dibutyryl cyclic AMP (db-cyclic AMP) had no effect on basal insulin secretion, but caused a marked enhancement of glucose $(20 \mathrm{mmol} / \mathrm{l})$-induced secretion.

Electrically permeabilised islets can be used to study the effects of small, normally impermeant molecules, which rapidly enter the Beta cells across the electrically permeabilised plasma membranes [7,8]. As shown in Figure 7 (lower panel), increasing the concentration of $\mathrm{Ca}^{2+}$ in the incubation medium, and thus in the intracellular compartment, from $50 \mathrm{nmol} / 1$ to $10 \mu \mathrm{mol} / 1 \mathrm{stimulated}$ insulin secretion from electrically permeabilised islets. However, the inclusion of cyclic GMP in the incubation medium at concentrations of up to $500 \mu \mathrm{mol} / 1$ had no effect on insulin secretion at either the substimulatory $(50 \mathrm{nmol} / 1)$ or the stimulatory $(10 \mu \mathrm{mol} / \mathrm{l})$ concentration of $\mathrm{Ca}^{2+}$. In contrast, cyclic AMP $(100 \mu \mathrm{mol} / 1)$ significantly enhanced insulin secretion from permeabilised islets at both $50 \mathrm{nmol} / 1$ and $10 \mu \mathrm{mol} / 1 \mathrm{Ca}^{2+}$.

\section{Discussion}

The physiological importance of $\mathrm{NO}$ as a cellular regulator is now widely accepted. In addition to its role as a regulator of vascular tone as the endothelium derived relaxing factor [2], NO is known to act as a cytotoxic agent produced by activated macrophages [18-20]. Evidence is also accumulating that NO may have widespread functions as a cellular regulator including, for example, as a neurotransmitter/neuromodulator in the central nervous system [21], or an anti-aggregatory second messenger in platelets [6].

In this context, we were interested to note that the constitutive form of $\mathrm{NO}$ synthase is $\mathrm{Ca}^{2+}$-activated $[6,21]$ since an initial event in the response of Beta cells to nutrient secretagogues is a rapid influx of extracellular $\mathrm{Ca}^{2+}$ through voltage sensitive $\mathrm{Ca}^{2+}$ channels [22]. The consequent increase in cytosolic $\mathrm{Ca}^{2+}$ might be predicted to ac-
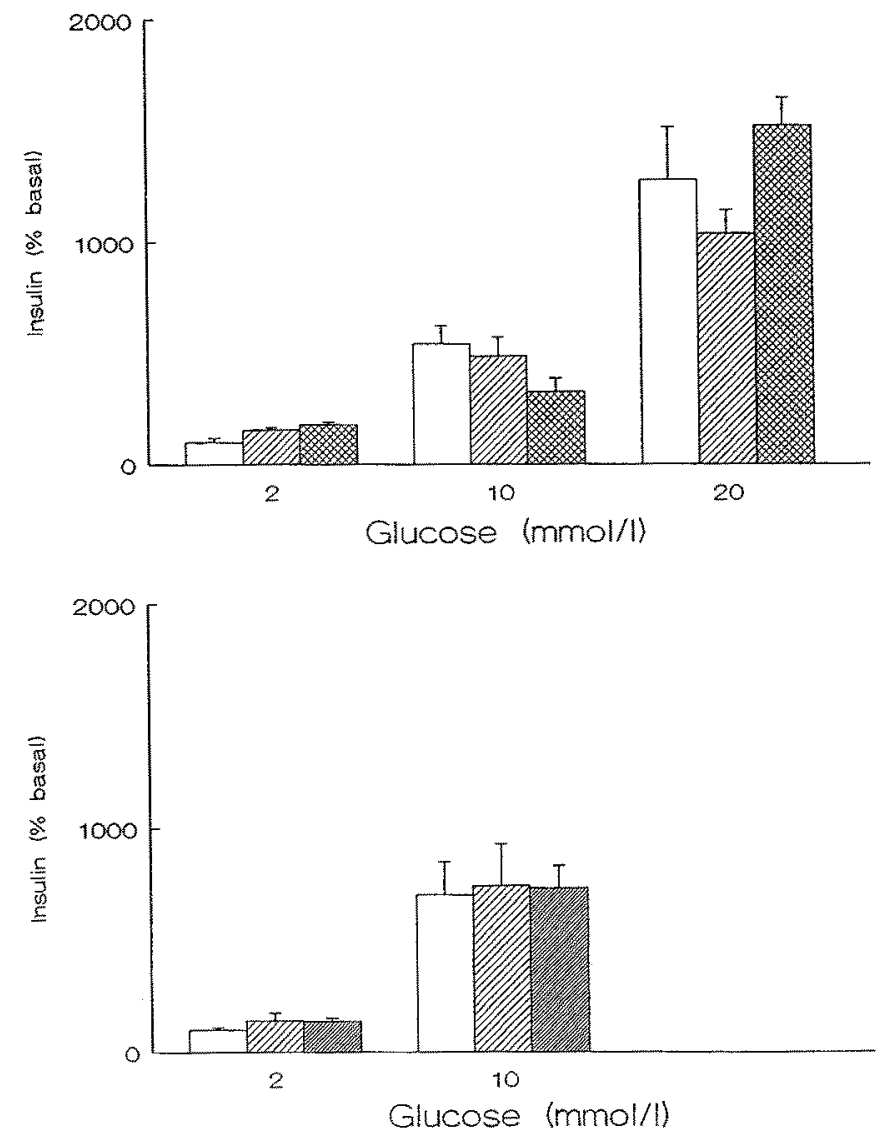

Fig. 4. Effects of $\mathrm{N}^{\mathrm{G}}$-monomethyl-L-arginine (NMA) and N-nitro-Larginine methyl ester (NAME) on glucose-induced insulin secretion from freshly isolated islets. Upper panel: Neither basal $(2 \mathrm{mmol} / \mathrm{l}$ glucose) nor glucose-stimulated $(10 \mathrm{mmol} / \mathrm{l}$ and $20 \mathrm{mmol} / \mathrm{l})$ insulin secretion from freshly isolated rat islets was significantly inhibited by the presence of NMA at concentrations of $100 \mu \mathrm{mol} / \mathrm{l}$ ( $500 \mu \mathrm{mol} / 1$ (登). Bars show means $+\mathrm{SEM}, n=6$ or $7, p>0.05$ for all appropriate comparisons. Lower panel: Similarly, NAME $(100 \mu \mathrm{mol} / / \mathrm{Z} ;, 1 \mathrm{mmol} / / \mathrm{m}$ ) did not affect $(p>0.2)$ either basal or glucose-stimulated $(10 \mathrm{mmol} / \mathrm{l})$ insulin secretion. $n=6$ or 7 


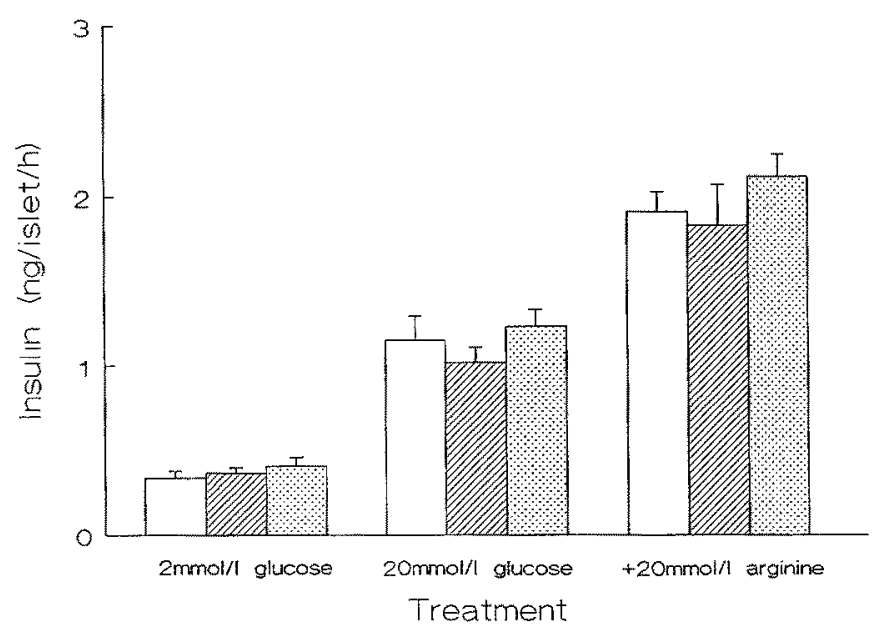

Fig.5. Effects of prolonged exposure to $\mathrm{N}^{\mathrm{G}}$-monomethyl-L-arginine (NMA) or N-nitro-L-arginine methyl ester (NAME) on insulin secretory responses. Exposure to $200 \mu \mathrm{mol} / \mathrm{l}$ NMA (ख) or $200 \mu \mathrm{mol} / 1$ NAME (3) for $20 \mathrm{~h}$ in RPMI 1640 medium (11 mmol/l glucose) did not inhibit $(p>0.2)$ subsequent insulin secretory responses to glucose $(20 \mathrm{mmol} / \mathrm{l})$ or to glucose plus arginine $(20 \mathrm{mmol} / \mathrm{l})$. Control islets $(\square)$ were cultured for $20 \mathrm{~h}$ in RPMI 1640 (11 mmol// glucose) alone. Note that under similar conditions, the presence of NMA or NAME completely blocked glucose-induced elevations in islet cyclic GMP, as shown in Figure 3. Bars show mean + SEM, $n=8$ or 9

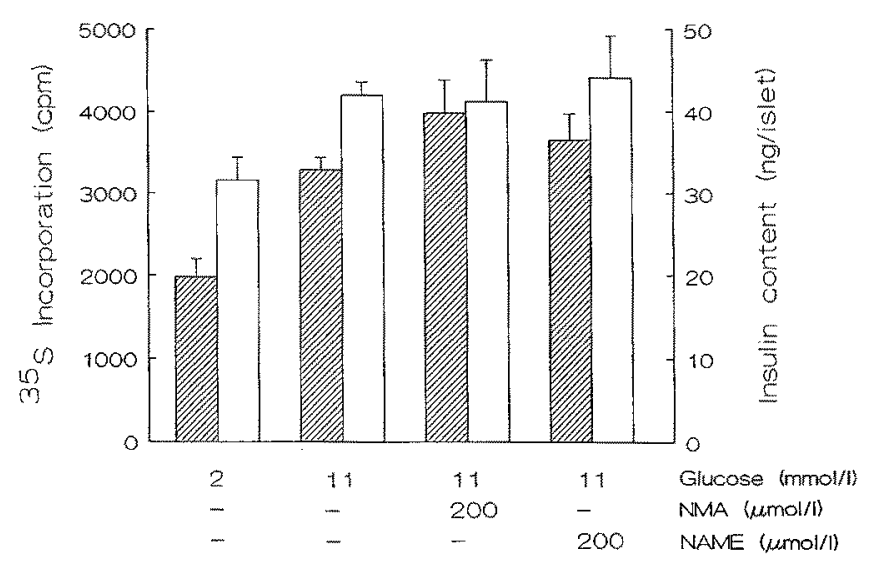

Fig. 6. Islet insulin content and biosynthesis: effects of glucose, $\mathrm{N}^{\mathrm{G}}$ monomethyl-L-arginine (NMA) and $\mathrm{N}$-nitro-L-arginine methyl ester (NAME). The figure shows ${ }^{35} \mathrm{~S}$-cysteine incorporation into (pro)insulin (罣, $n=5$ ) and insulin content $(\square, n=9$ ) of islets cultured for $20 \mathrm{~h}$ in media containing $2 \mathrm{mmol} / \mathrm{l}$ or $11 \mathrm{mmol} / \mathrm{l}$ glucose in the presence or absence of NMA or NAME, as indicated. Exposure to $11 \mathrm{mmol} / 1$ glucose significantly increased ${ }^{35} \mathrm{~S}$-cysteine incorporation and insulin content ( $p<0.01$ and $p<0.05$, respectively). NMA and NAME had no significant effects on glucose-induced insulin biosynthesis or insulin content $(p>0.2)$

tivate intracellular $\mathrm{Ca}^{2+}$-sensitive enzymes, as is thought to happen to phospholipase $\mathrm{C}$ in the Beta cell [23]. Furthermore, constitutive NO synthase requires NADPH [6, 21] and it is known that the metabolism of glucose, which is required for its secretagogue actions, produces rapid increases in NADPH levels within Beta cells [24]. However, in the present studies in which we simultaneously measured NO production and insulin secretion from rat islets we were consistently unable to measure NO gener- ation by islets in response to Beta-cell $\mathrm{Ca}^{2+}$-mobilising stimuli such as glucose, arginine or carbachol. Our parallel estimates of NO generation by porcine aortic endothelial cells in response to bradykinin are in general agreement with those reported by groups using on-line bioassay measurement of NO $[2,10]$, and suggest that if NO is generated by stimulated islet cells then the rate of production is at least of an order of magnitude less than that of endothelial cells in our experiments.

It cannot be entirely excluded that the insulin secretagogues did stimulate NO production by the Beta cells, but at rates below the detection limit of our assay system. Since one of the major effects of NO is to activate guanylate cyclase and thus increase cyclic GMP in target cells [12], we measured the effects of $\mathrm{Ca}^{2+}$-mobilising secretagogues on islet cyclic GMP content. Our measurements clearly demonstrated that the initiation of secretory responses to glucose, arginine or $\mathrm{CCh}$ was not accompanied by concomitant increases in islet cyclic GMP, although longer exposures to stimulatory concentrations of glucose did produce increases in islet cyclic GMP. There is no clear consensus on the effects of glucose and other secretagogues on cyclic GMP in islets or insulin-secreting tumour cells. Thus, stimulatory concentrations of glucose have been reported to cause rapid ( $2-3 \mathrm{~min}$ ) increases in islet cyclic GMP [5], in contrast to our measurements of unchanged levels of islet cyclic GMP after 15-min exposure to secretagogues. However, in some studies islet cyclic GMP was unchanged after exposure to stimulatory concentrations of glucose for up to $60 \mathrm{~min}$ [25-27], whereas in others, including the present study, exposure to glucose for $30 \mathrm{~min}$ or longer increased cyclic GMP content $[4,28]$. Whatever the reasons for these discrepancies, it seems likely that the marked glucose-dependent increases in cyclic GMP seen in the present studies after $20 \mathrm{~h}$ exposure to a stimulatory concentration of glucose were secondary to increased NO production since they were totally blocked by NMA or NAME. However, despite these effects of NO synthase inhibition on islet cyclic GMP, neither short-term nor prolonged exposure to NMA or NAME inhibited Beta-cell secretory responses, in accordance with previous studies using several NO synthase inhibitors $[3,29$, 30]. Although there is still some disagreement about the importance of cyclic GMP in the regulation of insulin secretion $[4,28]$, clear dissociations between elevations in islet cyclic GMP and insulin secretion have been reported $[26,28]$. In the present studies we too were unable to demonstrate an important role for cyclic GMP in the control of insulin secretion in experiments in which we supplied intact or permeabilised islets with exogenous cyclic GMP. Our results therefore suggest that secretory responses of Beta cells to glucose, arginine and $\mathrm{CCh}$ are not dependent upon the activation of $\mathrm{NO}$ synthase, nor upon the intracellular concentrations of cyclic GMP. Insulin biosynthesis, like insulin secretion, is a glucose-sensitive process and high concentrations of db-cyclic GMP have been reported to cause small increases in insulin synthesis in rat islets [25]. However, in our experiments treatment of islets with NMA or NAME prevented glucose-induced rises in cyclic GMP without affecting the stimulation of insulin biosynthesis by glucose, suggesting that changes in Beta-cell cy- 


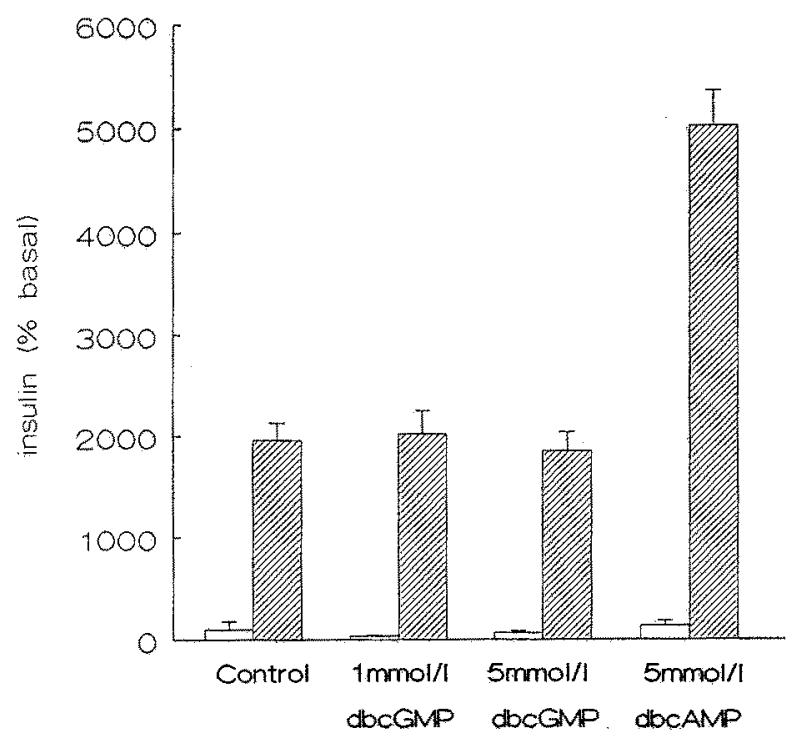

Dibutyryl cyclic nucleotide

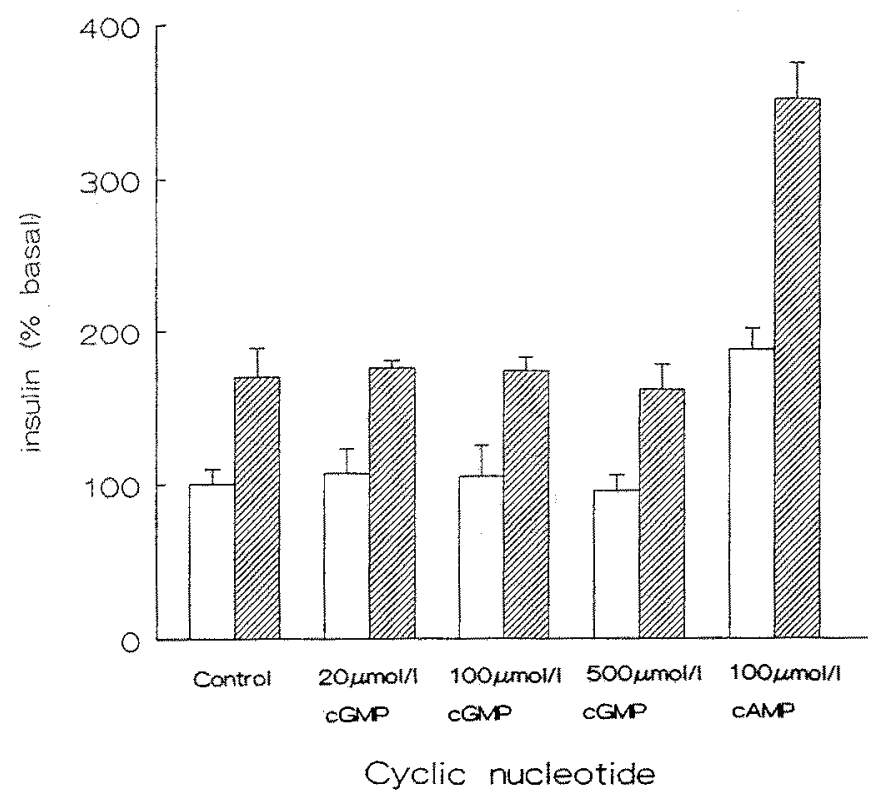

Fig.7. Effects of exogenous cyclic guanosine monophosphate (cyclic GMP) on insulin secretion. Upper panel: Dibutyryl cyclic (Db-c GMP) had no effect on basal ( $2 \mathrm{mmol} / 1$ glucose, $\square$ ) or glucose-induced $(20 \mathrm{mmol} / \mathrm{l} / 3)$ insulin secretion from intact islets $(p>0.2$ at all concentrations of db-c GMP). Db-c AMP had no effect on basal secretion, but markedly enhanced glucose-stimulated insulin secretion $(p<0.01)$. Bars show means $+\mathrm{SEM}, n=9$. Lower panel: In experiments using electrically permeabilised islets, cyclic GMP had no effect on basal $\left(50 \mathrm{nmol} / / \mathrm{Ca}^{2+}, \square\right)$ or $\mathrm{Ca}^{2+}$-induced $(10 \mu \mathrm{mol} / \mathrm{l}$, insulin secretion $(p>0.2$ at all concentrations of cyclic GMP). In contrast, cyclic AMP significantly increased both basal and $\mathrm{Ca}^{2+}$ stimulated insulin secretion $(p<0.01)$. Bars show mean + SEM, $n=9$

clic GMP do not regulate glucose-induced insulin biosynthesis.

It is therefore unclear what, if any, physiological function(s) are subserved by the increases in islet cyclic GMP observed in our experiments. The time-course and susceptibility to NO-synthase inhibitors suggest that the changes in islet cyclic GMP are secondary to the actions of an in- ducible form of NO synthase, and the glucose-dependence of the changes suggest an effect in the glucose-sensitive Beta cell. However, islets comprise a heterogenous population of endocrine and non-endocrine cells and we cannot exclude a glucose-sensitive activation of NO synthase in non-endocrine cells. In particular, NO has been implicated in the cytokine-induced destruction of pancreatic Beta cells which is thought to be associated with the development of diabetes mellitus $[3,18,30,31]$. Macrophages, in which NO synthase is the inducible form, are activated by cytokines and may act within islets as the NO generating cells for Beta-cell destruction $[18,31]$. The cytotoxic effects of NO on Beta cells are thought to be mediated by non-haem iron-containing proteins such as aconitase [30], rather than by the haemoprotein guanylate cyclase. The changes in islet cyclic GMP levels seen in our experiments are unrelated to insulin secretion, but are possibly an inescapable consequence of guanylate cyclase activation secondary to elevated NO levels in the islet.

Acknowledgements. Financial support from the Medical Research Council (MRC) and British Diabetic Association is gratefully acknowledged. P.M.J. is an MRC Senior Research Fellow (nonclinical). S. J.P. is a Wolfson Foundation Research Fellow. We thank Dr. D. Sugden (King's College London) for the kind gift of antisera against cyclic AMP and cyclic GMP.

\section{References}

1. Prentki M, Matschinsky FM (1987) $\mathrm{Ca}^{2+}$, CAMP, and phospholipid-derived messengers in coupling mechanisms of insulin secretion. Physiol Rev 67: 1185-1248

2. Palmer RMJ, Ferrige AG, Moncada S (1987) Nitric oxide release accounts for the biological activity of endothelium-derived relaxing factor. Nature $327: 524-526$

3. Southern C, Schulster D, Green IC (1990) Inhibition of insulin secretion by interleukin- $1 \beta$ and tumour necrosis factor- $\alpha$ via an $\mathrm{L}$-arginine-dependent nitric oxide generating mechanism. FEBS Lett $276: 42-44$

4. Laychock SG, Modica ME, Cavanaugh CT (1991) L-arginine stimulates cyclic guanosine 3', 5'-monophosphate formation in rat islets of Langerhans and RINm5F insulinoma cells: evidence for L-arginine: nitric oxide synthase. Endocrinology 129: 30433052

5. Schmidt HHH, Warner TD, Ishii K, Sheng H, Murad F (1992) Insulin secretion from pancreatic B cells caused by L-argininederived nitric oxides. Science 255: 721-723

6. Radomski MW, Palmer RMJ, Moncada S (1991) Modulation of platelet aggregation by an L-arginine-nitric oxide pathway. Trends Pharmacol Sci 12: 87-88

7. Jones PM, Stutchfield J, Howell SL (1985) Effects of $\mathrm{Ca}^{2+}$ and a phorbol ester on insulin secretion from islets of Langerhans permeabilised by high-voltage discharge. FEBS Lett 191: 102-106

8. Jones PM, Persaud SJ, Howell SL (1989) Time-course of $\mathrm{Ca}^{2+}$ induced insulin secretion from perifused, electrically permeabilised islets of Langerhans: effects of cAMP and a phorbol ester. Biochem Biophys Research Commun 162: 998-1003

9. Feelisch M, Noack EA (1987) Correlation between nitric oxide formation during degradation of organic nitrates and activation of guanylate cyclase. Eur J Pharmacol 139: 19-30

10. Kelm M, Feelisch M, Spahr R, Piper H-M, Noack E, Schrader J (1988) Quantitative and kinetic characterization of nitric oxide and EDRF released from cultured endothelial cells. Biochem Biophys Research Commun 154: 236-244

11. Gross SS, Stuehr DJ, Aisaka K, Jaffe EA, Levi R, Griffith OW (1990) Macrophage and endothelial cell nitric oxide synthesis: 
cell-type selective inhibition by $\mathrm{N}^{\mathrm{G}}$-aminoarginine, $\mathrm{N}^{\mathrm{G}}$-nitroarginine and $\mathrm{N}^{\mathrm{G}}$-methylarginine. Biochem Biophys Research Commun 170: 96-103

12. Ignarro LJ (1989) Endothelium-derived nitric oxide: actions and properties. FASEB J 3: 31-36

13. Bjaaland T, Jones PM, Howell SL (1988) Role of intracellular mediators in glucagon secretion: studies using intact and electrically permeabilized rat islets of Langerhans. $\mathbf{J}$ Mol Endocr 1 : $171-178$

14. Gey GO, Gey MK (1936) Maintenance of human normal cells in continuous culture: preliminary report; cultivation of mesoblastic tumors and normal cells and notes on methods of cultivation. Am J Cancer 27: 45-76

15. Bogle RG, Coade SB, Moncada S, Pearson JD, Mann GE (1991) Bradykinin and ATP stimulate L-arginine uptake and nitric oxide release in vascular endothelial cells. Biochem Biophys Res Commun 180: 926-932

16. Persaud SJ, Jones PM, Howell SL (1989) Effects of Bordetella pertussis toxin on catecholamine inhibition of insulin release from intact and electrically permeabilized rat islets. Biochem J 258: 669-675

17. Jones PM, Salmon DMW, Howell SL (1988) Protein phosphorylation in electrically permeabilized islets of Langerhans. Effects of $\mathrm{Ca}^{2+}$, cyclic AMP, a phorbol ester and noradrenaline. Biochem $\mathrm{J} 254: 397-403$

18. Kröncke K-D, Kolb-Bachofen V, Berschick B, Burkart V, Kolb H (1991) Activated macrophages kill pancreatic syngeneic islet cells via arginine-dependent nitric oxide generation. Biochem Biophys Res Commun 175: 752-758

19. Hibbs JB, Taintor RR, Vavrin Z, Rachlin EM (1988) Nitric oxide: a cytotoxic activated macrophage effector molecule. Biochem Biophys Res Commun 157: 87-94

20. Lancaster JR, Hibbs JB (1990) EPR demonstration of ironnitrosyl complex formation by cytotoxic activated macrophages. Proc Natl Acad Sci USA 87: 1223-1227

21. Crossin KL (1991) Nitric oxide (NO): a versatile second messenger in brain. Trends Biochem Sci 16: 81-82

22. Wollheim CB, Sharp GWG (1981) Regulation of insulin release by calcium. Physiol Rev 61: 914-973

23. Biden TJ, Peter-Riesch B, Schlegel W, Wollheim CB (1987) $\mathrm{Ca}^{2+}$-mediated generation of inositol 1,4,5-trisphosphate and inositol 1, 3, 4, 5-tetrakisphosphate in pancreatic islets. Studies with $\mathrm{K}^{+}$, glucose and carbamylcholine. J Biol Chem 262: 3567 3571

24. Pralong W-F, Bartley C, Wollheim CB (1990) Single islet B-cell stimulation by mutrients: relationship between pyridine nucleotides, cytosolic $\mathrm{Ca}^{2+}$ and secretion. EMBO J 9:53-60

25. Howell SL, Montague W (1974) Regulation of guanylate cyclase in guinea-pig islets of Langerhans. Biochem J 142:379-384

26. Vara E, Tamarit-Rodriguez J (1991) Does cyclic guanosine monophosphate mediate noradrenaline-induced inhibition of islet insulin secretion stimulated by glucose and palmitate? Biochem J 278: 243-248

27. Lin BJ, Henderson MJ, Niki H, Niki A, Haist RE (1975) Effects of acetylcholine and cGMP on insulin biosynthesis. Diabetes 24: $403-408$

28. Verspohl EJ, Ammon HPT (1989) Atrial natriuretic peptide (ANP) acts via specific binding sites on cGMP system of rat pancreatic islets without affecting insulin release. N-S Arch Pharmacol 339: 348-353

29. Jansson L, Sandler S (1991) The nitric oxide synthase II inhibitor $N^{6}$-nitro-L-arginine stimulates pancreatic islet insulin release in vitro, but not in the perfused pancreas. Endocrinology 128 : 3081-3085

30. Welsh N, Eizirik DL, Bendtzen K, Sandler S (1991) Interleukin$1 \beta$-induced nitric oxide production in isolated rat pancreatic islets requires gene transcription and may lead to inhibition of the Krebs cycle enzyme aconitase. Endocrinology 129:3167-3173

31. Bergmann L, Kröncke K-D, Suschek C, Kolb H, Kolb-Bachofen $\mathrm{V}$ (1992) Cytotoxic action of IL- $1 \beta$ against pancreatic islets is mediated via nitric oxide formation and is inhibited by $N^{6}$-monomethyl-i-arginine. FEBS Lett 299: 103-106

Received: 25 May 1992

and in revised form: 6 July 1992

Dr. P.M. Jones

Biomedical Sciences Division

King's College London

Campden Hill Road

London, W87AH

UK 